\title{
A Study on Channel 4's Station Identification: focused on 'Modular Typography'
}

I. INTRODUCTION

1. Background

2. Purpose and Scope

3. Theoretical Framework

II. HISTORY OF CHANNEL 4

1. Establishment and Branding of Channel 4

2. Elements of Station IDs

III. THE FIRST ICONIC '4' ID CONCEPT

1. Modular Typography

IV. SUBSEQUENT ICONIC '4' ID CONCEPTS

1. Examples of Channel 4 IDs

V. CONCLUSION

Reference

Abstract

Adjah John $\cdot$ Hong, Mi-Hee

\section{초 록}

영국 TV 채널인 채널 4는 세계적으로 가장 유명한 채널 중의 하나다. 그 채널 4 의 스테이션 ID 역시, 스테이션 아이디를 포함한 모션 그래픽 발전에 선두적인 역 할을 해왔다. 이 스테이션 아이디의 메인 디자인 컨셉은 이 채널의 이름이자 동시 에 상징적인 채널 4 의 로고 '4'이다.

채널 4 에서 처음으로 컴퓨터로 제작된 스테이션 아이디에는 모듈라 타이포그래 피가 사용되었다. 모듈라 타이포그래피는 글자를 비슷한 형태로 만들어내는 서체 디자인 기술인데, 채널 4의 스테이션 아이디는 컬러풀한 다각형으로 구성되어있다. 이 다각형들은 흩어졌다가 같은 3 디 초점으로 모여든다. 또한 채널 4 스테이션 아 이디의 모듈 방식은 비슷한 다각형들로 증명된다.

첫 번째 스테이션 ID 이후, 채널 4는 브랜화되었다. 특히 2004년부터 2011년 사이의 채널 4 스테이션 아이디에서 채널 4의 모듈 타이포그래피 특징들이 많이 보인다. 아이콘 ' 4 '는 돌, 건물, 빛 등의 자연적 환경과 인위적 환경으로부터 소재 를 갖고 온다. 이 논문에서는 채널 4의 역사, 첫 번째 스테이션 아이디와 그 이후 채널 4의 스테이션 아이디들에 적용된 모듈방식에 대한 시각적인 묘사가 포함되어 있다.

키워드: 모듈 타이포그래피, 스테이션 아이디, 채널 4 


\section{INTRODUCTION}

\section{Background}

Station Identification, popularly know as station ID is a practice of television or radio stations to identify their networks on air1). Station IDs have been in use for quite some time. The British Broadcasting Corporation(BBC) is an example of television stations, which identified itself on air around 1951. Station IDs serve a variety of purposes. The main purpose of a station ID in broadcasting is to let viewers know which station they are watching. Station IDs are also used to schedule programmes, brand new products and market the TV channel.

Station IDs are made up of various multimedia elements including typography, colour, sound, animation and other visual effects. All these elements are combined to with technology2) and software, to create an identity for a television channel.

Channel 4 is one of the most popular TV channels in Britain. Channel 4's station ID was first aired in September, 1982. It marked a new era of motion graphics. It was designed employing a technique in typography called 'modular typography' or 'modular construction'. The iconic '4' was used as the main visual symbol. Channel 4's station represents diversity and innovation of the channel. Following the original station ID which was constructed from coloured blocks, a number of them have been created using a

1) Brownie B. Transforming Type: New Directions in Kinetic Typography, Bloombury, 2015, Pg. ix

2) 한창완, 「디지털콘텐츠의 기술기반 진화모델연구」, 『한국만화애니메이션학 회』, Vol.-No.10 (2006), pp. 159-178. 
similar concept from modular typography.

Channel 4's station ID has been reviewed by other researchers all over the world. Notable among such researchers is Barbara Brownie (University of Hertfordshire, England), who has written, extensively, on the behaviour of fluid typography. This search paper will address the use and application of modular typography in Channel 4's first and subsequent station IDs.

\section{Purpose and Scope}

The main purpose of this research is a study of Channel 4' s station ID. Channel 4 is the focus of this research because its first concept of modular typography in 1982, is very creative and a point of reference for motion designers.

Another objective of this research is to identify the various ways modular typography is employed in the construction of subsequent Channel 4's station IDs.

In addition, this research also seeks answers to the relationship between modular typography and the principles of design and motion. Analysis will include the original station ID and other examples designed between 2004-2011.

\section{Theoretical Framework}

The framework for this study is based on the concept and application of modular typography. typography. Modular typography is a technique in typography. Modular typography is sometimes called modular lettering. It describes a technique of constructing typeface or letters that share common elements ${ }^{3)}$.

3) Willen B., Strals N., Lettering \& Type: Creating Letters and Designing Typefaces, Prineton Achitectural Press, 2009, Pg. 60 
The concept of modular lettering originated from a period when san serif typefaces began to create a new feeling of beauty in graphic designt). During the 1920s to 1930s, big foundries5) in Europe and America became very interested in expanding their typefaces. The san serif typefaces were considered 'modern' during this period because of its bold appearance. In 1928 a typographer from Munich, Germany designed a typeface called 'Futura'. This typeface is based on modular lettering because the letterforms share interchangeable elements eg. the 'o' is used for ' $b$ ', ' $c$ ', 'e', 'p' etc.

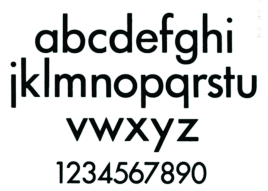

Figure 1. Futura Medium (Bauer)6)

Most of these elements in modular lettering are geometric in nature. Another thing about modular typeface is that they are san sanserif and devoid of calligraphic elements. Designers employ modular letters to create various effects in posters, movie titles, books, etc. This is because it is easy to manipulate their forms. In the 20th Century, some designers used this form of modular letterforms to create

4) Raizman D., (2003) History of Modern Design: Graphics and Products Since the Industrial Revolution, Lawrence King Publising Ltd, Pg 191

5) "The term "foundry" refers to a company that designs and sells retail fonts directly and/or through font distributors". Ruxandra Duru EINA," Type Foundries today, A study of the independent type foundry industry", 2011

6) Lawson A., Anatomy of a Typeface, David R. Gordine Publishing Inc.,1999, Pg 338 
various forms of effects in graphic design.

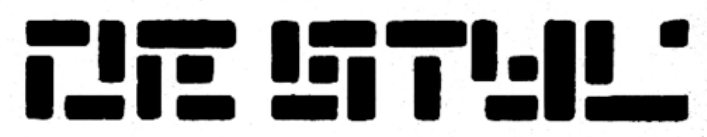

Figure 2. Theo Van Doesburg's typeface for De stijl Magazine7)

The above example is a typeface design by Theo Van Doesbury for De Stijl Magazine. In this title, the letters are simple rectangular units.

Channel 4' s used of modular typography is almost the same even though it is not a still image. The iconic ' 4 ' is made up of geometrical units like Theo Van Doesburg's typeface but used in modular construction. This study will analyse the behaviour of the units or modules in various forms of motion and how design principles are applied.

\section{BRIEF HISTORY OF CHANNEL 4}

\section{Establishment and Branding of Channel 4}

The Broadcast Act of Britain in 1980 proposed a new public service television channel. Channel 4 was established as a branch of the IBA (Independent Broadcasting Authority). The first station ID was launched on 2nd of November, 1982 as already stated in the introduction. On that day, television screens were suddenly filled with elegant display of coloured blocks of the channel's iconic '4' logo. The first director of the television channel was Jeremy Isaacs ${ }^{8)}$.

7) http://www. i conofgraphics.com/Theo-Van-Doesburg/

8) Hobson D, Channel 4: The Early Years and the Jeremy Isaacs Legacy, I.B. Taur is, 2008 Pg. 2 
Before Channel 4, there were only three channels in Britain; namely BBC 1, BBC 2 and ITV. Over the years after the launch of the channel, it helped in broadcasting very high quality contents to its viewers. Some of these are The Devils Whore, Red Riding, The Inbetweeners, Battlefront, Free Agents etc. Channel 4 also featured popular arts, religious and innovative educational programmes ${ }^{9}$.

Station IDs are part of a brand. A brand is not just the name of a company or TV Station. A brand involves all the characteristics of a TV station or company which makes it unique from other companies ${ }^{10)}$.

The major core values of Channel 4's brand are diversity and innovation. Channel 4 sought to create a brand that would reach out to all classes of people; thereby promoting its core values. To achieve this, Channel 4's logo and station ID was design by Lambie-Nairn. Lambie Nairn concept of the coloured blocks reflects the diversity and innovation of Channel 4. His concept of branding is based on basic rules namely; 'simplicity' and 'uniqueness'11). As seen in $<$ Figure 3>, Channel 4's iconic logo is very simple in form and very unique in design.

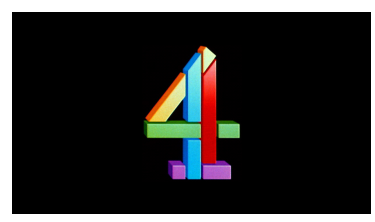

Figure 3. Channel 4's Original Logo by Lambie-Nairn12)

9) The House of Lords, The British Film and Television Industries--Decline Or Opportunity?, Volume II, ,2010 Pg 467-468

10) Lander R., Graphic Design Solutions 5th Edition, Wadsworth Cengage Learning, 2014, pg. 240

11) ht tp://labretgraphics.tumblr.com/post/118775070446/lambie-nairn 


\section{Elements of Station IDs}

Station IDs are played at various points of broadcasting, especially at the beginning and end of programmes. They make the viewers aware of the channel and they serve as 'teasers' to watch the next programme.

During a broadcast, a station ID may be played in between programmes. This is known as a commercial ID or a break bumper. It signals a break and resumption. Bumpers may not necessarily contain the main $\log ^{13)}$. Sometimes they are made up of colour themes. In branding new programmes, station IDs are created for advertising campaigns. These IDs are played to create awareness of a new event14).

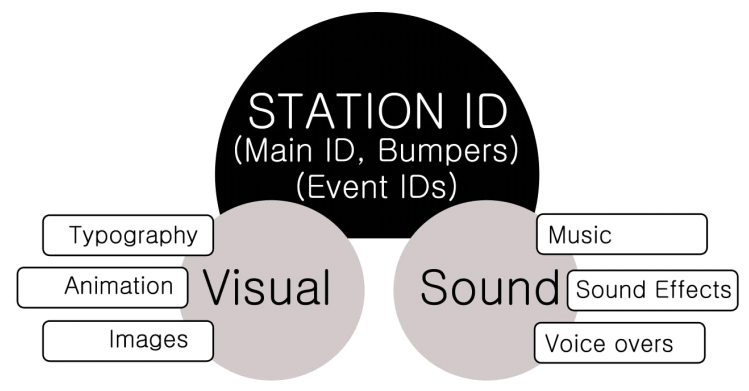

Figure 4. Elements of Station IDs

Station IDs include visual and sound components15). The visual make-up of a station ID constitutes animation of text and image. Text in station IDs is usually the logo and

12) http://www. lambie-nairn.com/case-study/channel-4/

13) https://en.wikipedia.org/wiki/Bumper_(broadcasting)accessed 2015.01.30

14) 이영미, 「애니메이션 기법을 활용한 TV방송국 Station ID 디자인에 관한 연 구」, 『한국애니메이션학회』, Vol. No. 3 (2007), pp.197-218

15) 임효영,이은석, 「TV채널 브랜딩요소를 통한 CATV Station ID의 인지효과연 구 : 케이블 채널 $\mathrm{OCN}$, ch CGV를 중심으로」, 『한국디자인지식학회』, Vol. No. 12 (2009), pp.35-44. 
tagline16). Image in station IDs is seen in the form of logos and other visual symbols, which are animated together with other images or footage to tell a story about the channel's brand. Animation in station IDs can be created by using traditional, stop motion or computer 2D/3D. Most station IDs these days designed using 2D/3D animation because it is very convenient and fast to complete projects.

The sound component in station IDs is also very important. Sound evokes emotion and expresses tone of the channel. Sound can be created in different ways; voice overs, music and effects. Voice overs are vocal recordings of phrases, channel names, tag lines etc. They can be also accompanied with real music. In the case of channel 4's original station ID, the iconic '4' responds to four sets of chords17). Sound effects are artificial sounds that are used to enhance the content of motion graphics. In station ID design, sound effects add an artistic effect to the animation sequence.

\section{THE FIRST ICONIC ' 4 ' ID CONCEPT}

\section{Modular Typography}

In the section, there will be an analysis of Channel 4's first iconic '4' concept. Channel 4's first iconic concept was a computerized station ID. It consists of 9 coloured polygons ${ }^{18)}$.

16) "A tagline is a short text which serves to clarify a thought for or is designed with a form of, dramatic effect".

https://en.wikipedia.org/wiki/Tagl ine accessed 2016.02.09

17) "A chord is a harmonic unit with at least three different tones sounding simultaneously." "A combination of three or more pitches sounding at the same time. Benward \& Saker, Music: In Theory and Practice, Vol. I, p. 67\&359. Seventh Edition, 2003.

18) Hobson D., Channel 4: The Early Years and the Jeremy Isaacs Legacy, 

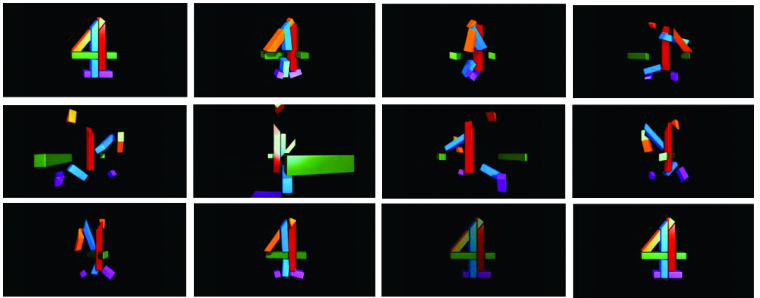

Figure 5. Channel 4 Station ID Sequence, 198219)

\begin{tabular}{|c|c|c|}
\hline $\begin{array}{c}\text { Animation } \\
\text { Style }\end{array}$ & Modularity & Design Principles and Motion \\
\hline 3D & $\begin{array}{c}\text { Coloured } \\
\text { polygons }\end{array}$ & $\begin{array}{c}\text { Unity, Proximity Variety, Contrast, } \\
\text { Perspective, }\end{array}$ \\
\hline
\end{tabular}

Table 1: Modularity in first Channel 4's station ID

In this station ID, which is 3D animation, the iconic '4' is visible at the beginning of the animation sequence. The number ' 4 ' as represented in the logo is the main visual symbol for channel 4. The logo is made up of nine basic polygonal units. These units can be called modules20) or primitives ${ }^{21)}$, just like the building blocks of lego toys. The coloured polygons split and fly in a rotating motion and finally converge to form the number ' 4 ' at the same point in 3D space. As the blocks split, there are series of abstract images. This action is accompanied with a background sound.

One basic principle in this animation sequence is unity. Looking at the way the modules or units transform, there is

\section{I.B. Taruis \& Co. Ltd, 2008}

19) https://www.youtube.com/watch?v=R86_TLuI51w,Accessed 2015.01.25.

20) Lupton E., Phillips Cole J, Graphic Design: The New Basics, Princeton Architectural Press, 2008, Pg. 161-167

21) Brownie, B."Modular construction and anamorphosis in Channel 4 idents: past and present". Journal of Media Practice, 14(2), 93-110. 10.1386/jmpr.14.2.93_1 
a unifying factor among the coloured polygons because they all split together on the axis. The principle of proximity allows perception of the various units as a whole.

Channel 4's first iconic ID has a variety of colours; representing the diversity of the channel.

The dark space in the background produces a sharp contrast with the coloured polygons. Contrast is a good principle in maintain a figure ground relationships, as found in gestalt theory.

Depth and perspective has been created by the addition of light effects. light effects create bright and dark tones and reveals its 3 dimension.

Channel 4's station ID is very innovative because the coloured polygons reflects creativity ${ }^{22}$. By using modular units of polygons, channel 4's ID is able to communicate an idea of diverse audience or groups.

The Space Squad station ID is also another version of Channel 4's first concept. It was also created by Lambie-Nairn for Channel 4 during the 25th Anniversary. This station ID is also made up of coloured polygons. However, these coloured polygons appeared to come from space. In the first frame, the iconic ' 4 ' is broken into splinters. As the objects draw closer, they reveal their 3D polygonal shapes. The overall effect is like a something emerging from the galaxy or space.

Motion in the Space Squad station ID is a little different from the first one. Motion begins with small dots or splinters. Unlike the first one which transforms by rotation, this one transforms in one direction. The coloured

22) McDonald P, Channel 4 and British Film Culture, Edinburgh University Press, 2014 
polygons converge in their original shapes in 3D space.
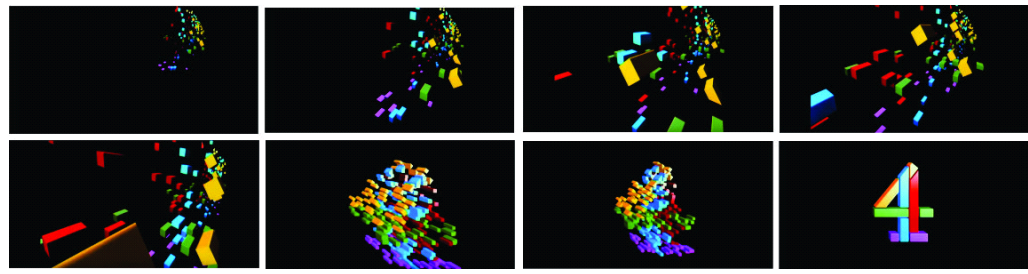

Figure 6. Channel 4 Space Squad IDs (25th birthday)23)

\section{SUBSEQUENT ICONIC '4' CONCEPTS}

\section{Examples of Channel 4 IDs}

Following the first station ID, a number of them have been created with the same iconic '4'concept. Technological development in 3D animation has also contributed to the superimposition of 3D animation on real life scenes. Subsequent Channel 4's IDs between 2004-2011 do not follow the exact geometrical concept of modularity, as seen in the coloured polygons; however all of them are constructed from units. These units are architectural and natural elements.

In the following list of selected station channel 4 IDs, some design thoughts will be analysed on how modular typography has been applied to create other station IDs.

23) https://www.youtube.com/watch?v=C4yEQGykeR0, Accessed 2016.01.25. 


\begin{tabular}{|c|c|c|c|}
\hline Year & Name & Modular Elements & $\begin{array}{c}\text { Design } \\
\text { Principles }\end{array}$ \\
\hline 2004 & Aliens & UFOs & \multirow{21}{*}{$\begin{array}{c}\text { Unity, Variety, } \\
\text { Repetition, } \\
\text { Similarity, } \\
\text { Proximity, } \\
\text { Cont inuity }\end{array}$} \\
\hline 2004 & Bowls & Grass hedges & \\
\hline 2004 & City Taxi & parts of a building & \\
\hline 2004 & Diner & Neon lights & \\
\hline 2004 & Estate & Old estate building & \\
\hline 2004 & Hay Bales & hay & \\
\hline 2004 & Market & market items & \\
\hline 2004 & Pylons & electrical cables & \\
\hline 2004 & Sign & Road signs & \\
\hline 2006 & Docks & $\begin{array}{c}\text { shipping yard } \\
\text { containers, cranes }\end{array}$ & \\
\hline 2006 & $\begin{array}{l}\text { Music } \\
\text { Stage }\end{array}$ & audio speakers, lights & \\
\hline 2006 & MPC Toyko & $\begin{array}{c}\text { Neon lights, electronic } \\
\text { banners }\end{array}$ & \\
\hline 2006 & Trafalgar & plinth & \\
\hline 2006 & Sofa & room items & \\
\hline 2007 & Seascape & rocks & \\
\hline 2007 & Dubai & building blocks & \\
\hline 2007 & $\begin{array}{l}\text { Roller } \\
\text { Coaster }\end{array}$ & roller coaster & \\
\hline 2009 & Simpsons & light streaks & \\
\hline 2010 & Airplane & broken down airplanes & \\
\hline 2011 & Abbey & stones & \\
\hline 2011 & $\begin{array}{l}\text { Usain } \\
\text { Bolt }\end{array}$ & Usain bolt, flood lights & \\
\hline
\end{tabular}

Table 2. Channel 4 Station IDs with Modular Concepts ${ }^{24)}$

As seen in <table 2>, these IDs bear names relating to their elements. One interesting fact about the behaviour of the iconic '4'as shown in the table is that it introduces itself as being present everywhere. It is able to create its identity from anything around its immediate environment. It shows up in places where you cannot imagine to see it.

24) http://www.thisisfive.co.uk/presbits/channel4/channel42004c.shtml 2015.01 .27 
The MPC Toyko ID, for example, is formed from architectural objects. MPC's Toyko station ID is set in the streets of Toyko. It is a combination of real life scene and 3D animation. In the first scene there is focus on the street whiles camera tracks a man riding a bicycle. As the camera moves along the street, there is hope of seeing something unusual. As the camera tilts ${ }^{25)}$ up the vertical axis, it begins to reveal something unexpected. Among the buildings the electronic banners begin to reveal a shape of ' 4 '.

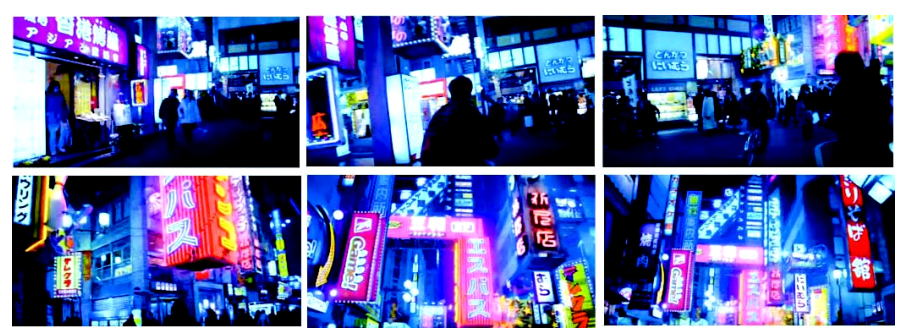

Figure 7. MPC, Toyko, 200626)

One fact which is consistent with modular typography, in this station ID, is that the iconic '4' is geometric in shape. The second fact is that the units of electronic signage are identical or similar in nature. Most electronic signage systems which display the names of restaurants and other shops in Toyko and other places are basically geometrical shapes; just like most buildings27).

The principle of proximity and unity here allows us to see the units as a whole, thereby seeing it as Channel 4 .

25) Van Sijll J., Cinematic Storytelling, Michael Wiese Productions, 2015, Pg 172

26) https://www.youtube.com/watch?v=R94X1M7r1SU accessed 2015.01.22.

27) B. Simon, Elements of Visual Design in the Landscape, Spoon Press, 2004, Pg. 54 
The Aeroplane Graveyard station ID is the next example for discussion. It is also a combination of 3D animation and real life scene. The scene is set in an old parking area for broken down airplanes. The sequence begins with a flying aeroplane that flies over an old parking area. The aeroplane then takes off to another scene where there many more aeroplanes can be seen. The iconic 4' logo is visible from a 'birds eye view' or 'overhead shot 28 ). As the camera moves away, the shape of the iconic ' 4 ' becomes more visible.

Modularity, therefore, in this station ID is a systematic arrangement of airplanes in the pattern of ' 4 ' as seen in the last frame.

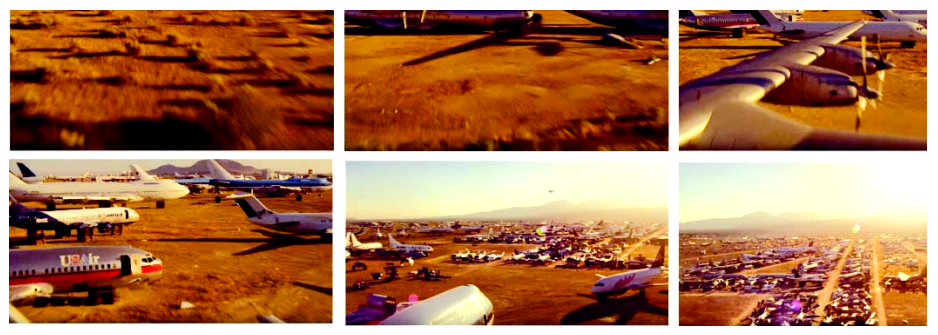

Figure 8. Aeroplane Graveyard station ID, 201029)

Again in this station ID, we see how the principle of unity and similarity is employed in the arrangement of airplanes in the parking area. It is also evident to see how the iconic ' 4 ' adapts to the environmental objects.

The Alien ID which features UFO (unidentified flying objects) is a station ID set in a deserted country side. The tone in this station ID is of a 'bizarre thriller' or

28) Mamer B, Film Production Technique: Creating the Accomplished Image, $5^{\text {th }}$ Edition, Wadsworth Cengage Learning, 2009, Pg. 9

29) https://www.youtube.com/watch?v=_hSrNMX5Fig/accessed 2015.01.24 
'horror', 30)which often characteristics 'Alien movies'. This station ID also focuses a little on the human characters. In the sequence, a man and a woman driving in their truck seem surprised and a bit terrified at the sight of unidentified objects. As they try to drive away from the lights, they see a stunning formation of the channel '4' logo behind them. The flying objects animate in fast pace. The human characters do not contribute directly to the modularity of the iconic 4 '; however, they set the stage for the animation to take place. Just like how Aliens appear in movies, Channel 4 uses this concept to create an aesthetic appeal for an audience group.

Obviously the identity of the iconic ' 4 ' is seen here which is a repetition ${ }^{31}$ principle. Looking at the iconic shape formed in this ID, there is a similarity in the units because they are all rectangular prisms. As a result of a real movie scene in this station ID, there is a use of movie storytelling techniques. One of them is climax ${ }^{32}$.

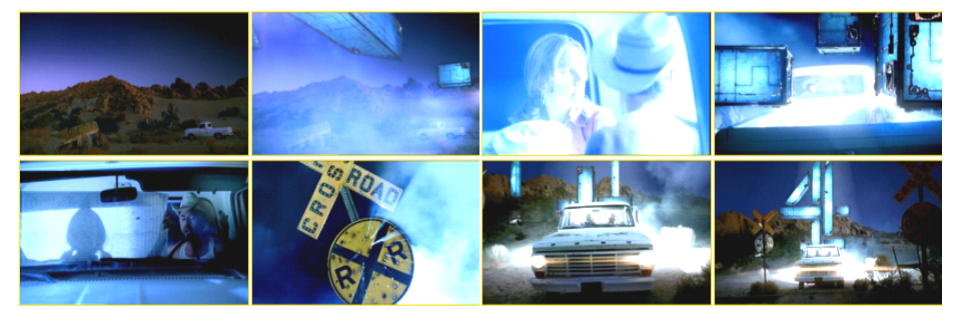

Figure 9. UFO Alien ID, 2004 33)

30) Kuhn A., G. Westwel, A Dictionary of Film Studies, Oxford University Press, 2012, Pg.211

31) Williams R. The Non-Designer's Design Book, Peachpit Press, 2008, Pg.51

32) Samaroo M., The Complete Guide to Writing a Successful Screenplay: At lant ic Publishing Group Inc. 2013, Pg. 210 
Another group of IDs are those created from natural objects. In the Bowls station ID, modularity is constructed from hedges ${ }^{34)}$. This station ID also involves the use of human characters who set the stage for animation. The scene is set in a bowling park with elderly class of people. In the first scene, focus is on the main activity which is bowling. This is done through the a mixture of close-up and medium shots ${ }^{35)}$. They are distracted as the hedges begin to rise into the air. The shape of the hedges is not visible. As they rise slowly on a bright sunny day, they cast a shadow of the iconic '4' from above. The shadow on the ground as shown in the animation sequence is a set of geometrical shadows in the shape of ' 4 '.

This station ID depicts recreational activities of the elderly class. It shows how Channel 4 aims at reaching out to every member of the society through its channel.
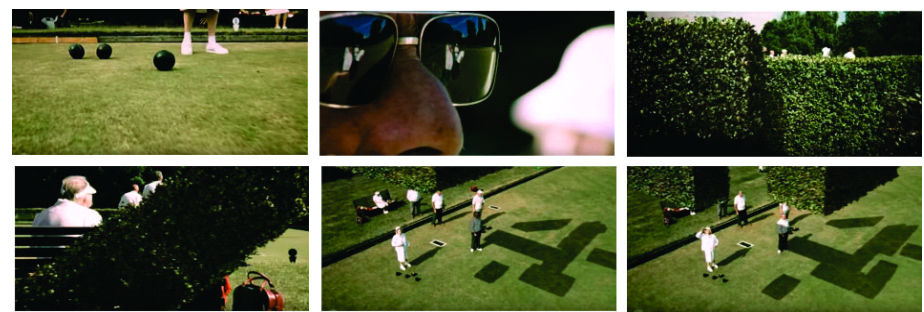

Figure 10. Bowls ID, 200436)

Some of the station IDs are also constructed from assorted

34)"a row of bushes or small trees planted close together, especially when forming a fence or boundary; hedgerow" http://dictionary.reference.com/browse/hedge?s=t accessed 2015.01.29

35) Mamer B., Film Production Technique: Creating the Accomplished Image, $5^{\text {th }}$ Edition, Wadsworth Cengage Learning, 2009, Pg. 9

36)http://www.thisisfive.co.uk/presbits/channe14/channe142004b.shtm l accessed 2015.01.29 
elements, usually synthetic. A very typical example is the Sofa ID. This ID is also a real life scene and 3D simulation. In this animation sequence, the iconic ' 4 ' is constructed from parts of the sofa which suspends in 3D space. As the camera gives an overhead shot, the '4' becomes visible.

Modularity, therefore, is applied in the simulated sofa. Just like all the other station IDs discussed in this paper, the principles of unity and proximity are dominant.

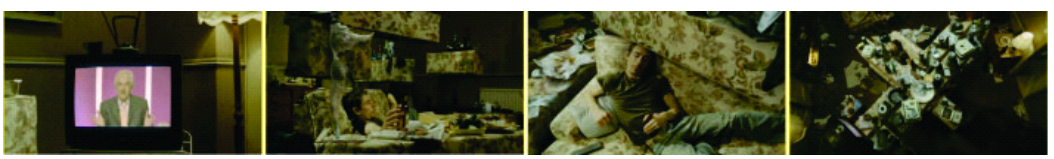

Figure 11. Channel 4 Sofa ID, 200637)

In all the station IDs analysed, one thing which is clear is the simplified forms and clear visual representation of the iconic '4. Station IDs must always persuade viewers and create an indelible mark in their minds.

\section{CONCLUSION}

In conclusion, this research has explored the various applications of modular typography in the construction of the original and subsequent Channel 4 station IDs.

Firstly, Channel 4's first iconic '4' is constructed from coloured polygons, which are geometrical in shape. These polygons form the iconic logo. Modularity in the original Channel 4 station ID is very evident because the iconic '4' is formed from similar polygons. These polygons transform by 
rotation in 3D space and converge to form the iconic ' 4 '.

Secondly, as seen in the analysis, the use of the iconic ' 4 ' has been maintained as the visual symbol. This is a principle of repetition in identity. The visual symbol is the same as channel 4' $\mathrm{s}$ logo. Channel 4's subsequent IDs use the iconic '4' visual concept, while applying the concept of modular typography.

Thirdly, Channel 4's subsequent station IDs, between 2004-2011, are constructed from natural and environmental elements. The iconic ' 4 ' uses the elements in its immediate environment to assume its identity. In most of these subsequent station IDs, the modular elements are not very geometrical as the first ID but give an illusion of geometry when they form the shape of ' 4 ' .

The fourth point is that there is a good use continuity and variety in the animation sequences. Continuity helps the viewer to connect scenes in the animation, especially in the short films eg. UFO Alien ID. Variety helps to sustain the viewer' $s$ interest to the message being transmitted.

The last most important principle which binds all the other principles is unity and proximity. Just like the coloured polygons, unity gives a sense of oneness among the iconic ' 4 ' elements. Proximity in the modularity allows the eye to perceive the units as a whole, thereby interpreting it as Channel 4.

\section{References}

Brownie B., Transforming Type: New Directions in Kinetic Typography, Bloombury, 2015, Pg. ix 
한창완, 「디지털콘텐츠의 기술기반 진화모델연구」, 『한국만화애니메 이션학회』, Vol.-No.10 (2006), pp. 159-178.

Willen B., Nolen S. Lettering \& Type: Creating Letters and Designing Typefaces, Prineton Achitectural Press, 2009, Pg. 60 Raizman D., History of Modern Design: Graphics and Products Since the Industrial Revolution, Lawrence King Publising Ltd,2003, Pg 191

Ruxandra Duru EINA," Type Foundries today, A study of the independent type foundry industry", 2011

Lawson A., Anatomy of a Typeface, David R. Gordine Publishing Inc., 1999, Pg 338

Hobson D., Channel 4: The Early Years and the Jeremy Isaacs Legacy, I.B. Taur is, 2008 Pg. 2

The House of Lords, The British Film and Television Industries--Decline Or Opportunity?, Volume II, ,2010 Pg 467-468

Lander R. Graphic Design Solutions 5th Edition, Wadsworth Cengage Learning, 2014, pg. 240

이영미, 「애니메이션 기법을 활용한 TV방송국 Station ID 디자인에 관 한 연구」, 『한국애니메이션학회』, Vol. No. 3 (2007), pp. 197 218

임효영,이은석, 「TV채널 브랜딩요소를 통한 CATV Station ID의 인지효 과연구 : 케이블 채널 $\mathrm{OCN}, \mathrm{ch} \mathrm{CGV}$ 를 중심으로」, 『한국디자인지 식학회』, Vol. No. 12 (2009), pp.35-44

Ellen Lupton E., Phillips Cole J., Graphic Design: The New Basics, Princeton Architectural Press, 2008 Pg. 161-167

Brownie, B. "Modular construction and anamorphosis in Channel 4 idents: past and present". Journal of Media Practice, 14(2), 93-110. 10.1386/jmpr.14.2.93_1

McDonald P., Channel 4 and British Film Culture, Edinburgh University Press, 2014

Van Sijll J. , Cinematic Storytelling, Michael Wiese Productions, 2015, Pg 172

Simon B., Elements of Visual Design in the Landscape, Spoon Press, 
2004, Pg. 54

Bruce M., Film Production Technique: Creating the Accomplished Image, 5th Edition, Wadsworth Cengage Learning, 2009, Pg. 9

Kuhn A., Westwel G., A Dictionary of Film Studies, Oxford University Press, 2012, Pg.211

Williams R., The Non-Designer's Design Book,Peachpit Press, 2008, Pg. 51

Samaroo M., The Complete Guide to Writing a Successful Screenplay: Atlantic Publishing Group Inc. 2013, Pg. 210

\section{Webpages}

ht tp: // labretgraphics.tumblr.com/post/118775070446/lambie-nairn ht tp://www. iconofgraphics.com/Theo-Van-Doesburg/

https://en.wikipedia.org/wiki/Bumper_(broadcasting) 2015.01.30. https://www.youtube.com/watch?v=C4yEQGykeR0, Accessed 2016.01.25. ht tps://www.youtube.com/watch?v=_hSrNMX5Fig/accessed 2015.01.24. ht tp://www.thisisfive.co.uk/presbits/channe14/channel42004c.shtm l 2015.01.27.

ht tp: //www. thisisf ive.co.uk/presbits/channe14/channel42004b.shtm l accessed 2015.01.29.

http://dict ionary.reference.com/browse/hedge?s=accessed 2015.01.29 


\section{ABSTRACT}

\section{A Study of Channel 4's Station Identification: focused on 'Modular Typography'}

Adjah John · Hong, Mi-Hee

British TV Channel 4 is one of the famous TV Channel in the world. Its station ID has also played a leading role in the developments of Motion Graphics including station IDs. This station ID' $s$ main visual design concept is its name and an iconic logo ' 4 ' at the same time. The first channel 4 station ID was designed by using modular typography to construct the iconic '4'. Modular typography is a technique of creating letters with similar elements. Channel 4 's station ID was constructed from coloured polygons. The polygons split and converge at the same point in 3D space. Modularity in Channel 4's station ID is evidenced by the similar units of polygons. After the first station ID, Channel 4 was re-branded. Eventhough the station IDs which followed did not use coloured and geometrical polygons, modularity is seen in most of the station IDs especially between 2004 - 2011. In these station IDs, the iconic '4' is formed from similar natural and environmental objects like rocks, buildings, lights etc. In this analysis paper, there is a visual narrative on the history of Channel 4, the concept of modular typography in the original station ID and the application of modular typography in other Channel 4's station IDs.

Key Word : Modular Typography, Station ID, Channel 4

Adjah John (MA Course student)

Department of Visual Communication Design Hanbat National University joniblaze2002@yahoo.com

Hong, Mi-Hee (Professor)

Department of Visual Communication Design Hanbat National University mhhong@hanbat.ac.kr 
논문투고일 : 2016.02.01.

심사종료일 : 2016.02.24.

게재확정일 : 2016.03.03. 